\title{
Towards Conflict Transformation and Management skills' training in Zimbabwean Primary School Teacher Education for effective Teaching, Learning and Peace in Zimbabwean Primary School: A Case Study of Mkoba Teachers' Training College.
}

\author{
Thondhlana Saiden \\ Lecturer in the Department of Educational Studies \\ Zimbabwe Open University
}

\begin{abstract}
The purpose of education is to address societal problems. Conflicts in schools like in any organization are inevitable. If these are not managed and transformed they affect negatively learning, teaching and peace in schools. There is therefore, need to manage and transform conflicts in schools. Imparting conflict resolution skills is both imperative and necessary in schools and teacher educational colleges. The study was sparked off by a realization that conflict management and transformation was downplayed in teacher educational colleges resulting in the absence of programmes aimed at addressing this very important area. The study focused on establishing the curriculum that was to be exposed to student teachers in teacher educational colleges in a bid that these students could subsequently impact the knowledge, skills and attitudes into their pupils when they completed their training. The sample for the study was 20 student teachers and 10 teacher educational college lecturers who were purposively chosen. A qualitative research methodology was employed. A case study design was adopted. The major findings of the study were that the teacher educational college curriculum covers much of the areas on conflict resolution, the teacher education curriculum however, does not cover areas such as mediation, ethics and good manners, interdependence of nations, bullying, cooperative learning academic controversy, methods used in teaching students adequately, assessment was largely norm-referenced and schools did not do areas of the Health and Life skills as in colleges. The study recommended that the teacher educational college curriculum was to cover left out areas, assessment was to be criterion-referenced, the school curriculum was to be in sync with the teacher educational curriculum.
\end{abstract}

KEY TERMS: Teacher education, Conflict resolution, Curriculum, Zimbabwe.

\section{INTRODUCTION}

A number of researchers have recommended the introduction of conflict resolution in primary schools in Zimbabwe (Moyo and Tumbo, 2013; Nziramasango Report in Education and Training, 1999). Even if the primary school curriculum has conflict resolution issues this is not enough. Conflict resolution issues training has to begin in the Teachers' Colleges so that systemic reform is maintained. Some researches on how issues of conflict resolution were being addressed in teacher's colleges have been carried out in Zimbabwe. One research that was undertaken was done by Shumba, Manokore, Silitshena, Sango, Dhlomo and Mdondoro (2005). This study was undertaken at Mutare Teacher's College in Manicaland and it concentrated on how the teachers' college was addressing issues on growing up and sexual maturation. The study found little evidence of the college imparting knowledge on interpersonal relations which is one aspect of conflict resolution. 
Another study was undertaken by Makoni (2015). It was undertaken at two teachers' colleges in urban Mutare. The findings of the study were; Zimbabwean teachers' colleges are not offering courses in peace education, peace education would benefit Zimbabwe as a country, peace education is implementable at pre-service teacher education and the need to develop an appropriate peace education curriculum that reflects the needs of Zimbabwean citizens.

The researcher got interested in establishing how a primary school teachers' college in the Midlands was equipping trainees with conflict resolution skills so that they could in turn impart the skills to their pupils when they embark on teaching. Teacher's colleges have been given the lee -way to develop their syllabuses autonomously (Gatawa, 1998; Chivore, 1994). This implies that teacher education colleges might end up with different curricula for different areas of study they offer.

Makoni (2015) recommended that teachers' colleges were to introduce peace education in their pre-service programmes in order to build prospective teacher capacities to establish infrastructure for positive peace in their future classrooms, the immediate communities and the Zimbabwean society as a whole. Peace education needs therefore, to be made compulsory for all prospective teachers. Peace education in teachers' colleges can initiate a culture of peace on a systematic basis, starting in teachers' colleges and emanating in the schools and communities (Ssenkumba, 2010). For peace education to succeed in schools several school structures have to support its implementation and dissemination (Hantzopoulous, 2011). Peace education is considered to be essential in determining how teachers learn and succeed in the real classroom and school situations (Pandey, 2011).

\section{STATEMENT OF THE PROBLEM}

Recommendations from researchers hold that conflict resolution issues are supposed to be introduced in schools but for this to happen effectively this has to be introduced in Teachers' Colleges. This is not the case presently in teacher education colleges in Zimbabwe. The main research question for this study is how are the Teachers' colleges addressing training of conflict resolution skills to equip student trainee teachers so that they are equipped to consequently train their pupils when they complete training?

\section{Sub - problems of the study}

The study set out to explore the following sub - problems:

- What content in the syllabi and policies addresses conflict transformation, management and peace building in the teachers' colleges?

- To what extent are the methodologies in the syllabi relevant for conflict management and peace education?

- In what ways are teachers' college administrative procedures promotive of conflict transformation, management and peace building?

\section{PURPOSE OF THE STUDY}

The purpose of the study was to establish how the primary teachers' colleges were equipping student trainees with skills which they would subsequently transmit to their children on completion of their courses.

\section{SIGNIFICANCE OF THE STUDY}

The study was important to teacher trainers in that they established how conflict transformation, management and peace building would be effectively transmitted to student teachers. The study was also important to curriculum planners in teacher education in that 
they would come up with an appropriate curriculum for conflict transformation, management and peace building. The study was also important to teacher training administrators in that they found out how their administrative procedures would be promotive of conflict transformation, management and peace building.

\section{LIMITATIONS OF THE STUDY}

The study had a limitation. The limitation was that the study was a case study so the data collected could not be generalised for the whole country because the study was confined to one teacher educational college. Thus the strategies could not be applied to all other teacher education college in the country.

This limitation was circumvented by triangulation of sources of information and data gathering techniques.

\section{DELIMITATIONS OF THE STUDY}

The study was delimited to one teacher educational college in the Gweru District of the Midlands Province of Zimbabwe. Only participants from lecturers and student trainees that could be accessed were invited to participate. Document analysis was also undertaken. The study focused on the aspects of conflict resolution in the teacher educational curriculum.

\section{Conceptual Framework The Concept Conflict}

\section{REVIEW OF RELATED LITERATURE}

Various authorities understand conflict from diverse perspectives as demonstrated by the definitions advanced by a number of experts in education. Differences in viewpoints are inevitable, and often enriching. Unanimity is more unlikely when we consider that, in addition to natural differences such as male and female, there are those brought about by a range of other dimensions: status, power, wealth, age, the role assigned to our gender, belonging to a specific social group, and so on (Fisher, Abdi,Ludin, Smith, Williams \& Williams, 2007, p. 3). These indicators of position in society often mean that people want different things from the same situation, sometimes these goals clash, or are incompartible. It is then there is a conflict. Rue and Byars (2003, p. 285) contend that conflict is "an overt behaviuor that results when an individual or group of individuals think a perceived need of the individual or group has been blocked or is about to be blocked". This definition stresses the importance of basic needs like physiological needs, security needs, social needs, self- esteem and self- actualisation (Maslow, 1991).

Fisher et al., (2007, p. 3) say that "conflict is a relationship between two or more parties (individuals or groups), who have, or think they have, incompartable goals".

However, Wright (1951) cited in Sellman (2003, p. 23) uses the Latin word "confligere" meaning to strike together. Wright (1951) cited in Sellman (2003) says confligere has two meanings, one that highlights conflict as a fight, battle or prolonged struggle between opposing forces, which can include beliefs and ideas that may result in a physical clash and another meaning which states that conflict can occur psychologically, as emotional distress between incompartable wishes within a person. In this context, conflict has both a conceptual as well as a behavioural property at both individual and group levels. The duality of conflict is emphasised by Fink (1968) cited in Sellman (2003, p. 25) who views conflict as any social situation or process in which two or more social entities that are linked by at least one form of antagonistic psychological relation (internal conflict) or at least one form of antagonistic interaction (external conflict). 
Conflicts are a fact of life, inevitable and often creative. Conflicts occur according to the definitions given above, when people pursue goals which clash. Disagreements and conflicts in schools are usually resolved without violence, and often lead to improved situation for most or all of those involved. Conflicts arise from imbalances in relations. That is, unequal social status, unequal wealth and access to resources and unequal power (Fisher et al., 2007, p. 4).

\section{Conflict Resolution}

Conflict resolution is applying ways of resolving disputes that will leave the previous disputing parties restoring their previous relationships. So many definitions of conflict resolution have been advanced by different authorities. Some of these definitions are discussed below.

\section{The Meaning of Conflict Resolution}

Conflict resolution is the process of resolving a dispute by providing each side's needs and adequately addressing their interests so that the disputing parties are satisfied with the outcome. Conflict resolution aims to end conflict before it starts to lead to physical fighting (Lam, 1988). Conflict resolution implies managing disagreements before they lead to aggression or violence.

Conflict prevention, management, resolution and transformation (CPMRT) is understood as a systematic way of trying to deal with conflict in a professional way which is not corporal (Tumbo \& Moyo, 2013).

Conflict may be resolved through diverse ways including analysis, negotiation, mediation; conciliation, facilitation, arbitration and judicial settlement (Johnson \& Johnson, 1995; Robbins, 2001). The major principle of conflict resolution is to separate people from the problem, focusing on interests not positions, investing in options for mutual gain and using objective criteria as the basis for decision-making and the problem solving process that is negotiation, mediation and consensus- decision making (Crawford \& Bodine, 1996). They are therefore, aspects of collaboration toward a compromise or consensus decision. Negotiation can be aided by good working relationships, persuasive value systems and "soft power" (Johnson \& Johnson, 1995).

Morton (1991) defines conflict resolution as a constructive approach to interpersonal and intergroup disagreements that helps people with opposing positions to work together to arrive at mutually acceptable solutions. Morton (1991) confines conflict resolution to resolving interpersonal and intergroup conflict and refers to conflict resolution as an approach which helps people in conflict working together to come to a mutually acceptable compromise.

Conflict resolution is a broad term that refers to many ways of resolving disputes. It creates a relationship not characterised by hierarchy but one marked by equality, participation, respect, mutual enrichment and growth (Morton, 1991). It is aimed at addressing the causes of conflict and seeking to build new lasting relationships between hostile groups.

\section{The Theoretical Framework of the Study}

The study was premised on social pedagogy theory. Hatton (2003) cites The Social Pedagogy Development Network defining Social Pedagogy as an academic discipline that draws on Care theories from various related disciplines such as education, sociology, psychology and philosophy. In essence, it is concerned with the well-being, learning and growth of a child. This is underpinned by humanistic values and principles which view people as active and 
resourceful agents, highlights the importance of including them into the wider community and aims to tackle or prevent social problems and inequalities.

This is done through active involvement of the people concerned and getting their views despite their differences.

Petrie, Buddy, Cameron, Wigfall and Simon (2006) posit that social pedagogy emphasises team work and valuing the contribution of others in bringing up children. The child is seen as a social being, connected to others and at the same time with their own distinctive experiences and knowledge.

ThemPra (2015) advances the following aims of social pedagogy:

- It is holistic education that is education of the head (cognitive knowledge) heart, (emotional and spiritual knowledge) and hands (practical and physical skills).

- It creates a holistic well-being that is strengthening health sustaining factors.

- It enables children to grow up as self-responsible persons who take responsibility for their society and

- It promotes human welfare and prevents or eases social problems.

Conflict resolution is viewed as fulfilling the above aims of Social Pedagogy and therefore, any strategies designed should lead to the fulfillment of these aims.

ThemPra (2015) advances the following pathways as Social Pedagogy;

- Providing opportunities for learning,

- Building strong and positive authentic relationships which are non-hierarchical,

- Enabling children to empower themselves,

- Working with the head, heart and hands in everyday activities and

- Cultural impact on what is possible in practice.

Conflict resolution is therefore, viewed as enhancing the personal, relational approach in student's training and education where fostering sound pedagogical values and attitudes is seen as important as the acquisition of knowledge and skills. Petrie et al., (2006) posit that pedagogues (teachers) are trained in such issues as group-work, working with conflict and challenging behaviour, teamwork and working with disabled children. The teachers' colleges are therefore viewed as institutions that should have these issues in their curricula.

ThemPra (2015) states the social pedagogy has emerged to address culturally specific problems through educational means and as every culture encounters their own unique problems, solutions to social problems are highly dependent.

Furthermore, Petrie et al., (2006) contends that social pedagogy builds on an understanding of children's rights not limited to procedural matters or legislated requirements so teachers in practice and in their training are supposed to be prepared in sharing in many aspects of the children's daily lives and activities. It therefore, means children's associative life is seen as an important resource which teachers should foster and make use of in their teaching.

Social pedagogy also emphasises the centrality of relationships and the importance of listening and communication (Petrie et al., 2006). These are central issues in conflict resolution.

The above views of social pedagogy are in line with the unity-based world view. The key principles of this world view are the recognition that: 
- The world is one,

- Humanity is one,

- Humanity's oneness is expressed through infinite diversity of talents, thoughts, tasks, physical characteristics and life experiences,

- The central challenge of life is to create unity in the context of diversity and

- To successfully meet this challenge, we need to learn how to resolve conflicts in a peaceful and just manner. Maintaining unity while recognising diversity in the world is a mammoth task.

In the Unity-Based world view:

- Institutions aim to achieve justice through participatory, consultative process,

- Individuals and groups seek opportunities for growth and development,

- Human relationships are based on truthfulness, equality and service,

- The essential oneness and wholeness of the human race is recognised and all forms of prejudice and segregation are rejected,

- Women and men participate equally in the administration of human affairs and

- Human development and prosperity are achieved through application of universal ethical principles and processes of consultative decision making and governance (Danesh and Danesh, 2002).

Lastly, social Pedagogy is underpinned by the practical (Petrie et al., 2006). This implies the use of certain methods and creative activities. Conflict resolution strategies require children and adults practise how to transform and manage conflicts.

The study is also premised on the systems theory. A system, according to Kasambira (1998, p.44) is "a set of interrelated elements that function as a unit for a specific purpose". The systems theory suggests that an organisation must be studied as a whole taking into consideration the inter-relationships among parts and the external environment. In this study the colleges that train teachers were interrogated.

\section{Empirical Review of related Literature}

\section{The Curriculum and Conflict Resolution in Schools and Teachers' Colleges.}

Researchers like Crawford and Bodine (1996) and Coleman and Duestch (2001) refer to two approaches of the process curriculum and peaceable classrooms as useful approaches to conflict resolution in primary schools. The process curriculum is characterised by devoting a specific time to teaching the foundation abilities of conflict resolution, principles of conflict resolution and one or more of problem-solving, processes of conflict resolution as a separate course, distinct curriculum, or daily lesson plan (Crawford \& Bodine, 1996). The Peaceable Classroom approach is a whole classroom methodolody that includes teaching students the foundation abilities of conflict resolution, principles of conflict resolution and one or more aspects of problem-solving namely negotiation, mediation and consensus decision-making. Conflict resolution is incorporated in the core subjects of the curriculum and into classroom management strategies (Crawford \& Bodine, 1996). These two approaches imply having conflict resolution in the school curriculum.

The Peaceable Classroom approach views the curriculum as "what happens in real school situations as a result of planned programmes" (Gatawa, 1990:8). It is seen in other words as what happens to children as a result of what teachers do. It, therefore, is the totality of the experiences of a child or groups of children that takes place within the classrooms and school 
grounds or outside the school. It is viewed as the official curriculum, the operational curriculum, the hidden curriculum and the extra curriculum (Posner, 1995).

\section{Content and Conflict Resolution}

Conflict and conflict resolution in its various forms may form the content of one or a series of lessons (Sellman, 2003). In Austria, for example, the Centre for Citizenship Education in schools (2012) has designed five modules on "everybody has rights". The modules have five areas that they handle namely "Fighting together' aimed at non-violent conflict management and communication, "Respect all" aimed at building esteem and self-esteem, "Borders lost" which deals with personal and structural limits, "we are a class" which deals with issues of class community and team building and "It brings diversity" which deals with diversity, similarities and differences as well as with the foreign and familiar.

This programme in Austria uses participatory and interactive methods which help pupils experience the opportunity to participate in exercises where they learn about the issues, that is, they dramatise situations and discuss issues freely. The contents of the modules are adapted to respective age groups. Participants in the learning do role playing, collages, design songs or do pantomimic skill images of issues.

Also regarding the issue pointed out by Sellman (2003) above, Morton (1991) reports of there being in New York in America what was known as the Resolving Conflict Creatively Programme (RCCP). The RCCP is a curriculum based programme. It was a collaborative effort between New York City's Board of Education and a nonprofit group Educators for social responsibility (ESR). RCCP began in 1985 with 18 teachers and by 1991 had over 1000 teachers and 30000 students in 100 elementary and secondary schools and was also involved in special education programmes.

The RCCP had a ten unit curriculum with lessons on intergroup relations, cooperative learning and dispute resolution techniques. The teachers involved in RCCP set aside lessons for conflict resolution but were encouraged to infuse conflict resolution skills into other subject areas.

Coleman and Deutsch's (2001) report of schools and districts in the United States of America advocate for conflict resolution concepts and skills into the curriculum either as a course that stands alone or as a unit within existing programmes.

The curricula provided lessons and activities for pre-schoolers to University level focused on such themes as, understanding conflict, communication, dealing with anger, co-operation affirmation, bias awareness, cultural diversity, conflict resolution and peace- making. Most of the programmes use a cooperative problem-solving process in their delivery.

In line with the curriculum for conflict resolution, Murray (2000) also developed Primary school level curriculum for children's Rights Education. This curriculum is known as "the world around us" and the materials developed address children's rights of provision, protection and participation. These issues are addressed using five thematic modules namely Module 1, respect, rights and responsibilities; Module 2, children, families and friends; Module 3, education, learning and growing; Module 4, food, health care and homes and Module 5, safe, friendly and peaceful world. Murray (2000) goes on to give details of what is in each module and how the material is to be presented. This material could be included in the teacher education curriculum. 
Saiden, T. (2017). Towards Conflict Transformation and Management skills' training in Zimbabwean Primary School Teacher Education for effective Teaching, Learning and Peace in Zimbabwean Primary School: A Case Study of Mkoba Teachers' Training College. Advances in Social Sciences Research Journal, 4(16) 1-22.

In England and Wales according to Sellman (2003) there is a National Curriculum subject referred to as citizenship in secondary schools and primary schools. The subject aims to endorse the political values of pluralism and democracy. Included in this subject are common values like, truth, honesty, trust and a sense of duty. Schools are also mandated to consider to what extent their ethos, organisation and daily practices were consistent with the aim and purpose of citizenship education and also provision of opportunities for pupils to develop into active citizens (QCA, 1998 cited in Sellman, 2003). According to the above information, schools are required to relate their organization and pedagogic practice to a broader and more active notion of education which emphasises the experiential as well as the intellectual. This could be done through creation of school councils, school parliaments and peer mediation services. In Zimbabwe the Zimbabwe Report of the Presidential Commission, Nziramasanga commission into Education and Training (1999) recommended the introduction of Civic Education in schools. This material could also be included in the teacher education curriculum.

Elsewhere, Gorter (1986) documents what is emphasized with regards to conflict resolution. Gorter (1986) points out that in Ontario, Canada, values and personal responsibility in society at the international level are taught in relation to religious beliefs, while England and Wales emphasize respect for religious and moral values, tolerance of other races and ways of life, an understanding of the world in which others live and the interdependence of nations. England and Wales also emphasise knowledge of human achievements and aspirations. Japanese students are expected to grow up as citizens who love people everywhere in the world and who will obtain the trust and respect of the international society. The above types of activities are goals intended to foster conflict resolution at international level. In Zimbabwean primary schools such issues as ethnocentricism and xenocentricism are present (Mavhunga, 2006; Makuvaza, 2008; Marashe, Ndamba and Chireshe, 2009). If the above information could be infused into the teacher education curriculum it would go a long way into eradicating ethnocentrism and xenocentricism.

Regarding bullying, McEachern, Kenny, Blake and Aluede (2005) advance the following recommendations and strategies that the programmes to reduce incidences of bullying in school must start early in the elementary grades and that children are to be educated about bullying to increase awareness of the seriousness of these acts and be taught conflict resolution and problem solving skills to help them resolve disputes without resorting to violence or use of derogatory remarks. The above authorities also recommended The Peace Education Foundations (PEF) curricular materials to educate students, teachers and parents, which deal with the dynamics of conflict, how to deal with conflict non- violently and promotion of peace making skills in homes, schools and communities. Bullying is reported as a menace in a number of primary schools in Zimbamwe (Mapolisa \& Tshabalala, 2012; Team Zimbabwe, 2015). Adoption of the PEF curricular materials in the Zimbabwean teacher education curriculum would go a long way in reducing bullying in schools.

In the Philippines, according to Miranda and Echano (2005) a subject known as Makabayan was introduced in 2002. Makabayan deals with social studies in grades 1 to 3. The Social Studies consist of civics, culture, music, arts and Physical Education. In grade 4 to 6 Makabayan deals with Social Studies consisting of Geography, History and Civics, Home Economics and Livelihood, Music, Arts and Physical Education. Good manners and right conduct are integrated into all learning areas. Makabayan particularly at grade 6 level, focuses on the democratic system and the rights, duties and responsibilities of citizens. Makabayan on the whole is a laboratory of life aimed at developing a healthy personal and national self identity. Makabayan uses integrated units of learning to enable the learners to process, assimilate and 
systematically practise a wide range of values and life skills including work skills and work ethics (Miranda and Echano, 2005). It also lays stress on the development of social awareness and responsibility, empathy and a firm commitment to the common good. Miranda and Echano (2005) also gave a detailed account of the core values and human rights concepts to be learnt in each area at various grade levels.

In the United States of America, the University of Florida, College of Education (2012) has developed conflict resolution and social problem solving curriculum materials. This curriculum is a school wide programmme for $6^{\text {th }}$ to $8^{\text {th }}$ grade students. The curriculum consists of five units namely, understanding conflict, effective communication, understanding anger, handling anger and peer mediation.

Palmer (2001) suggests several ways in which three types of conflict that occur in schools namely conflict over resources, conflict of needs and conflict of values could be resolved through teaching. Palmer suggests that these could be prevented by children learning about other's customs, beliefs, history, problems, hopes and dreams and that in diversity students could be provided with opportunities to present their own points of views. Palmer (2001) also suggests the teaching of deescalating conflict, using the techniques of Ki Aikido which is a Japanese martial art that is based at the study of energy, tense situations, win-win strategies, active listening and decision making. Children's literature can be used in developing correct attitudes.

In Zimbabwe there are no studies aimed at establishing the aspects in the curriculum that could be carriers of conflict resolution skills development and the gaps to be filled so that the curriculum could be used as a tool for conflict resolution skill's development except studies by Marashe, Ndamba and Chireshe (2009; Makoni, 2015). Marashe, Ndamba and Chireshe (2009) undertook a study to establish the teaching of Traditional Religion in Zimbabwean primary schools. The study entailed a content review of the primary school Religious and Moral Education syllabus. Another study was undertaken by Makoni (2015). It was undertaken at two teachers' colleges in urban Mutare. The findings of the study were; Zimbabwean teachers' colleges are not offering courses in peace education, peace education would benefit Zimbabwe as a country, peace education is implementable at pre-service teacher education and the need to develop an appropriate peace education curriculum that reflects the needs of Zimbabwean citizens. There was, therefore, need to undertake a study to establish how the college curriculum is a carrier of material for conflict resolution skills' development and the gaps to be filled.

The curriculum is not only made up of the content but also entails how the content is delivered that is, the methodologies employed, the assessment undertaken and the hidden curriculum as already alluded to earlier.

\section{Curriculum Methodologies and Conflict Resolution}

The researcher now reviews literature on the appropriate methodologies. Regarding methodologies for peace education Abebe, Gbesso and Nyawalo (2006) observe that the traditional passive lecture methodologies are in contradiction with the requirements of learner-centred (participatory, interactive and co-operative learning) required in peace education. Fountain (1999) concedes that learner friendly methods promote values and behaviours conducive to peace. She points out that participatory approaches build up cohesion, reduce bias and lead to the development of problem-solving skills among students. Fountain (1999) outlined the following as some of the participatory methodologies used in peace education programmes; co-operative group work, peer teaching, small group discussions, 
decision making and consensus building exercises, negotiation, role play and simulations. Amatruda (2006) recommends action techniques and psychodrama methods to be used on a bi-weekly basis to help students communicate more positively with one another allowing them to improve their status with peers in the classroom after use and evaluation with children of 10 to 13 years in an elementary school special education programme. It was found that students' negative behaviour in the classroom decreased, interactions with one another were more positive and attitudes toward their own potential increased as a result of the psychodrama based conflict resolution and skill-building training. In Zimbabwe, no study has been undertaken to establish whether the methodologies in the primary school curriculum could be used to promote the development of conflict resolution skills development.

\section{Assessment and Conflict Resolution}

Regarding assessment, Harris (2003) points out that assessment should centre on the effects of peace education on learners' attitudes, thought patterns, behaviours and knowledge gained while Fountain (1999) cites the following assessment methods as appropriate for peace education: interviews, focus group discussions, review of school records, observation, rating scales, questionnaires and surveys.

The above mentioned techniques are only a few examples of curriculum programmes that have been introduced in the primary school system in various parts of the world which could aid the researcher in finding out what aspects one has in the education system and which would need to be addressed. In Zimbabwe, assessment is mainly norm-referenced (Chakanyuka, 1995).

\section{Peer Support and Training}

Peer support exists in a variety of ways. The strategies include peer mentoring ( 0 'Connel, 1995), peer counselling (Kaye and Webb, 1996) and peer mediation already discussed (Unwin and Osei, 2000).

These types of intervention strategies provide support from within the pupil's immediate community, peers rather than adults. Pupils appear more willing to trust each other and they are less likely to receive sanctions (Sellman, 2003). Adults rarely have sufficient time to devote to inter-pupil conflict and can sometimes perceive as trivial what is important to children (Rawlings, 1996, cited in Sellman, 2003). There are quite a number of practical strategies children could use in real life situations like "Anger Rules" (Douglas, 1999), Red: stop, Amber: Think and Green: Do. The use of these mediational devices encouraged children to extend the thinking time between action and reaction which is a crucial ingredient of emotional intelligence and management of relationship (Goleman, 1996 cited in Sellman, 2003). Researches on the effectiveness of these training techniques have shown that children are receptive to such training particularly at an early stage (Sellman, 2003). There is no evidence of the use of peer support and training in Zimbabwean primary schools.

Another strategy pointed out by Sellman (2003) which is in use especially in United Kingdom schools is Pastoral care. The discussion switches over to a discussion of this strategy.

\section{Whole College Cultural Approaches and Conflict Resolution in Schools}

Whole school approaches to tackling violence in schools have been found to yield good results (Salisbury and Jackson, 1996). Schools need to examine the relationship between aggressive behaviour and their own organisations, policies, discipline and teaching styles. Individual intervention strategies on their own, tend to have a limited impact (Sharp and Thompson (1994) cited in Sellman, 2003). Nelson, Martella and Marchand-Martella (2012) suggest four 
components of the school wide programme. These are first, the ecological arrangements of common areas of the school that is hallways, cafeteria, rest rooms and playground. Second, there is establishment of clear and consistent behavioural expectations. Third, there is active supervision of common area routines to prevent disruptive behaviour from occurring and to respond effectively when it does occur. Finally, there is use of empirically validated disciplinary response policies and procedures by classroom supervisors in order to stabilise how staff members respond to problem behaviours in the classroom. In the first year of the programme consensus- building and participatory planning should be undertaken.

Another school wide technique could be open classroom meetings (OCM) proposed by Emmett and Monsour, (1996). These meetings are intended to promote communication and personal relationship skills, listening skills, ability to communicate feelings and problem- solving skills. They are also promotive of mutual respect for each other's differences.

In OCMs children learn to express their own thoughts and feelings and to develop the attitudes and skills necessary to listen to thoughts and feelings of others. Through OCMs children and teachers increase their understanding of and empathy for each other. Increased understanding often leads to increased respect and appreciation for differences and contributions of all class members. Members of the school community also begin to feel more cared for and to care more for each other. Emmett \& Monsour (1996) cited Glasser (1969) suggests three types of OCMs namely problem-solving meeting, educational-diagnostic meeting and open ended meeting. OCMs, however, require the following skills: active listening, accurate paraphrasing, identification of feelings and open-ended questioning.

The whole school approach though requiring a huge investment in time and effort requires an initial firm establishment and needs to incorporate the consultation of the wider community (Benthey, 1998 cited in Sellman, 2003). The involvement should continue into implementation. The initiative also needs regular monitoring, evaluation and modification where necessary (Sellman, 2003). There is need for dialogue, direction and cohesion within the school which needs to extend to external agencies and the community served by the school. There should be participation by teachers, the administration staff and parents in framing behaviour management policy and its implementation as a continuous cycle of application, review and modification (Daniels et al., 1998).

Regarding participation, a variety of strategies could be used. These could include quality circles (Robbins, 1993), informal methods (Stoner, Freeman and Gilbert, 1995), committees (Appleby, 1994) democratic centralism structures (Gwarinda, 1993) and suggestion boxes (Appleby, 1994).

In this participation influential members of the school community should give on-going support to whole school cultural change needs. Sufficient commitment to the changes is necessary. When this commitment is available, reduction of violent incidents could be seen within a year (Sharp and Thompson, 1994 in Sellman, 2003).

The issues to be attended to are community relationship, value, organisation, environment, curriculum and training. In Zimbabwean schools the child friendly programme is one such programme.

Supportive environments include the following according to Cohen (1995):

- Cooperation between school and community in developing policies, 
- Values of cooperation and non-violence, which permeate all school relationships and teaching styles,

- Principles of school organisation and pedagogic practice built upon notions of equality, inclusiveness and non-violence,

- An environment that is conducive to co-operative behaviour,

- A curriculum that attends to issues of both content and process conflict resolution skills and

- Pupils being given both the training and opportunity to learn how to resolve conflict for themselves.

- If conflict is difficult to resolve it can be arbitrated.

The whole school approach should have clear conflict management policies and procedures. This would be integrated with school policy areas such as equal opportunity, antiharassment/bullying, welfare, discipline, occupational health and safety policies. The whole school approach also advises that school administration should model affective management of conflict, staff should model positive, co-operative and collaborative relationships as well as using co-operative processes in the classrooms. This material ought to be exposed to students in teacher educational colleges.

\section{METHODOLOGY}

The study adopted the qualitative research paradigm. This is so because the researcher intended to find issues requiring common sense knowledge of people (Lederach, 1997). A case study design was adopted. Multiple case studies were employed. These were intrinsic case studies where no attempt was made to generalise beyond the single case or even to build theories (Silverman, 2010). The study used quester - views, open - ended interviews, document analysis and focus groups discussions. The quester-view enabled the researcher to gather data because it is easy to construct and cheaper to administer (Denzin, 1997). Individual in-depth interviews enabled participants to express unique or controversial perspectives without fear of censure (Cresswell, 2008). Focus group discussions are collective interviews. In collective interviews participants, through their interaction could provide data and some insights which could not be revealed through interviews with individuals. Focus groups result in collective synergy (Kruger \& Casey, 2000 cited in Gall et al, 2007). The documents were used to establish content, assessment, methodology and administrative issues that relate to conflict and conflict resolution in the primary teachers' colleges. The analysis provided insights into strategies which were employed to develop conflict solution skills, attitudes and knowledge in children and adults. Documentary analysis is a careful examination of documents and their contents in order to draw conclusions about the social circumstances in which the documents were produced and read (Bloor and Wood, 2006). The sample consisted of 20 student teachers and 10 college Lectures. Both samples were purposively selected. Only those who showed interest were chosen. The researcher followed Merriam's (2009) analysis of qualitative data. The study was undertaken within three months. This time allowed for member checking.

\section{FINDINGS}

\section{Findings on How Teachers' Colleges are Equipping Teachers with Skills for Resolving Conflict and Helping Pupils to Resolve Conflict}

The findings are presented according to emerging themes on content, methodology, assessment and management practices. Shumba et al., (2005) posit that themes for the primary schools should be similar to themes to be addressed in the teachers' colleges. In the teachers' college the Health and Life skills department was found linked to conflict resolution. 


\section{Content of the Teachers' College Curriculum and Conflict Resolution}

The document analysis, lecturer and student participants' reactions revealed the following themes regarding the content; promotion of self-esteem and social skills, inculcation of conflict resolution skills, promotion of respect for differences/values of pluralism, problem solving skills development, human rights awareness and inculcation of gender issues.

\section{Promotion of Self-Esteem and Social Skills}

Document analysis established with regard self-esteem and social skills promotion that the Mkoba Teachers' College Health and Life Skills syllabus (2010) covers such issues as selfawareness, interpersonal relationships, empathy and coping with emotions.

All focus groups and interviewees revealed that a lot of issues on building self-esteem and social skills are handled during Health and Life Skills sessions. The participants in the interviews and focus group discussions produced the following excerpts on the issue.

We cover with student teachers material on building self-esteem and dealing with emotions (Lecturer).

In health and life skills we are subjected to how we should socialize. We believe this will help us to teach our children how to socialize when we complete our courses (Student teacher).

\section{Inculcation of Conflict Resolution Skills}

Document analysis revealed that one of the aims of the Health and Life Skills programme is developing students' skills of communication, negotiation and conflict resolution. Conflict resolution skills' content includes effective communication, coping with stress, negotiation and conflict resolution.

The focus groups and interviewees pointed out that much about conflict resolution is found in the syllabus. Issues handled include negotiation, arbitration and mediation. The participants in interviews and focus group discussions produced the following excerpts regarding the development of conflict resolution skills:

- When students are taught skills of communication and conflict resolution they can communicate appropriately during negotiation and in conflict resolutions they handle such issues as arbitration issues that are so pertinent in conflict resolution (Lecturer).

- Attitudes towards the infested and affected and life skills to operate in different environments foster the respect for differences in students which issues are necessary in conflict resolution. It is believed that when the students learn these ideas they will also transmit these to their children as they teach later (Lecturer).

- We only cover negotiation and arbitration as ways of conflict resolution (Student teacher).

- While we are equipped with much information on conflict resolution at college in the Health and Life skills programme, but when we get into schools the programme is still the HIV/AIDS action programme that existed before and does not cover much of the areas we will have covered (Student teacher).

- Students also cover material that we feel is relevant to conflict resolution in applied education as we interpret subject syllabuses particularly in Social Studies, Religious and Moral Education, Music and Physical Education (Student teacher).

- I am a recently graduated teacher I want to point out that the Health and Life skills programme equipped us with much of the needed conflict resolution material but it appears when we get into schools we are not given the chance to practise what we will have learnt for we teach the HIV/AIDS action education which does not have much of 
what we will have covered in the Health and Life skills programme (Recently graduated teacher)

- What the above excerpts potray is that while colleges cover material in the Health and Life Skills syllabus that address conflict resolution, the school curriculum has not changed. In the schools there is still the existence of the HIV and AIDS programme which leaves some aspects covered in the Health and Life Skills programme. Applied Education, however, does furnish them with content related to conflict resolution.

\section{Promotion of Respect for Differences/Values of Pluralism}

Findings from document analysis revealed that the Mkoba Teachers' College Health and Life Skills syllabus (2010) has as one of its aims, developing in teacher trainees' attitudes towards the infected and affected persons and equipping them with life skills to operate in different environments. The objective to address the aim was demonstration of sensitivity to vulnerable groups, gender issues and human sexuality. The content taught included vulnerable groups, orphans, the girl child, widows and widowers, the physically challenged, people living with HIV, the poor and aged and those living with albinism. These disadvantaged people were object of derision and isolation.

Participants in interviews and focus group discussions produced the following sentiments: The following areas are covered with much depth; effective communication, decision -making, problem solving, self-awareness, creative thinking, interpersonal relationships and coping with stress and students do role play to grasp the content (Lecturer).

We cover much ground in effective communication, decision making, problem solving, selfawareness and interpersonal relationships issues inclined to conflict resolution (Student Teacher).

\section{Human Rights Awareness}

Document analysis revealed that the Health and Life Skills syllabus aims at making students aware of human rights. The student teachers in turn see the need to uphold children's rights. Human rights content includes children's rights and child abuse. The upholding of children's rights is likely to reduce friction between children and teachers.

The focus groups and interviews submitted that human rights awareness was handled in much depth. One participant during an interview said the following about human rights awareness in the teacher's college curriculum:

One area that we cover in detail is children's rights. This helps us to minimise conflict between teachers and children (Student teacher).

\section{Problem Solving Skills' Development}

Document analysis established that the Mkoba Teachers' College Health and Life Skills syllabus (2010) aimed at developing in the student teachers problem solving skills, decision making and creative thinking skills which should enable the trainees to resolve conflicts among pupils in the primary schools.

The participants in interviews and focus group discussions expressed the following about problem solving skills development:

There is exposure to problem solving as students are presented with problems that they are likely to meet and they are required to solve in groups (Lecturer). 
Our lecturers give us problems to resolve problems after every lecture. We enjoy these sessions because they teach us how to think and resolve problems (Student Teacher).

\section{Awareness of Gender Issues}

Document analysis of Mkoba Teacher's College, revealed that the Health and Life Skills programme included such issues as differences between gender and sex, gender and blindness and its effects, gender sensitivity and its benefits, gender and religion, gender mainstreaming and domestic violence.

The participants in the interviews and focus group discussions revealed the following details about instilling awareness of gender issues in the student teachers:

We expose our students to various issues regarding gender that include gender sterio types, gender and religion, gender and sex and gender and blindness among other issues (Lecturer).

In this college we get exposed to a lot of issues regarding gender like what gender is, issues regarding equality, gender and religion and gender and disability (Student Teacher).

\section{College Curriculum Methodologies and Conflict Resolution}

The themes established with regard to curriculum methodologies and conflict resolution were the use of cooperative group work, peer teaching, small group discussions, decision making and consensus building and role play.

\section{Use of Cooperative Group work}

Documents examined revealed that the Health and Life Skills syllabus promotes the use of cooperative group-work. Focus group and interviews revealed the use of cooperative group work in the delivery of the matter in the area. The following excerpts from the participants in interviews and focus group discussions confirm use of cooperative group work:

Our students are made to work in cooperative work groups when they discuss issues related to Health and Life. They enjoy such occasions and we are hopeful they will employ such strategies with their classes (Lecturer).

We are made to help each other understand issues taught through participation in cooperative workgroups. This strategy really enhances our understanding of the material we will have learnt (Student Teacher).

\section{Use of Peer Teaching}

Document analysis established that the Health and Life Skills syllabus indicated use of resource persons. The resource persons could be students who were knowledgeable in conflict resolution content areas. Focus group and interview findings revealed the use of resource persons in the delivery of some topics.

The following excerpts from the participants in interviews and focus group discussions confirm the use of peer teaching:

Some of us students are used to deliver material on certain areas we are knowledgeable. This urges all students to want to take part (Student teacher).

When we establish students who are good in certain areas we make them deliver that material to fellow students (Lecturer).

To be effective students are urged to do adequate research on topics assigned to them. 


\section{Use of Small Group Discussions or Focus Group Discussions}

Document analysis revealed thatthe Health and Life Skills curriculum is also taught through discussions. These discussions could be held in small groups. This is encouraged in conflict resolution. Focus group and interview findings established the use of small discussions in the delivery of the matter.

The excerpts that follow show the use of discussion groups in developing skills that help trainee teachers to resolve conflicts among pupils they would eventually teach upon completion of their studies:

Students take part in small group discussions on issues that we will have lectured to them. These are in the form of seminars (Lecturer).

Ehm! We take part in small discussions on how certain conflict situations could be resolved. We are presented a case and discuss how to resolve the case (Student teacher).

The above confirm the use of small group discussions on skills development.

\section{Fostering Decision Making and Consensus Building}

Document evidence showed that research and Case Studies were undertaken in Health and Life Skills enabling students to make decisions and it also developed consensus building. Discussions on what had been observed during educational visits might lead to consensus building.Focus group and interviews established the use of research and Case Study methods.

The following excerpts emphasise the use of methods for decision making and consensus building:

As students are given cases to discuss they come up with decisions. Some decisions require them to come up with a consensus. They report back on their decisions (Lecturer).

We are so excited when we reach decisions from our discussions. This is very empowering (Student teacher).

\section{Role Play}

Document analysis findings revealed that the Health and Life Skills syllabus encourages the use of role play. Role play has been found as an effective way of conveying conflict resolution content particular aimed at change of attitudes. The participants in interviews and focus group discussions reflected the use of role play in conveying matter in the Health and Life Skills syllabus as exemplified by the following excerpt:

The following areas are covered in much depth, effective communication, decision -making, problem solving, self-awareness, creative thinking, interpersonal relationships and coping with stress and students do role play to assimilate the required knowledge (Lecturer).

\section{Assessment in Teachers' College and Conflict Resolution}

Three ways of assessment of material taught in the Health Skills syllabus were revealed. There are assignments, seminar presentations and examinations. In some practical areas practical examinations are given and teaching practice assessment and supervision is carried out to assess the students' ability to teacher and the expected teacher behaviour. 


\section{Assignments}

Focus group and interview findings established that the assignments are mainly essay type assignments. These encourage students to communicate ideas clearly and concisely. This is necessary in negotiation, arbitration and mediation in conflict resolution.

The following excerpts attest to the use of assignments as a form of assessment: We give our students two assignments termly (Lecturer).

We are pressurised with assignments after we have learnt the material (Student teacher).

The above excerpts confirm that students are assessed using assignments in the Health and Life Skills programme.

\section{Use of Seminar Presentations}

Focus group and interviews revealed thatthe other way the content is assessed is through seminar presentations. Students are given the chance to present their views and these are discussed by the group. This is quite vital in conflict resolution. Seminar presentations help student teachers to order their ideas and present their points of view well. These skills are required in negotiation, arbitration, mediation and academic controversy in conflict resolution. The lecturers and students had this to say:

We present seminar papers to peers. After the presentation the paper is discussed. Other students add to our ideas (Student teacher).

Seminar presentations help our students to analyse issues and in that way they develop skills of critiquing and consider ideas of fellow students (Lecturer).

Document analysis established that the other form of assessment of the value of the Health and Life Skills content is through examinations. Examinations are also given in the Applied Education areas. The examinations are norm-referenced. They are standardised.

Lecturers had this to say about examinations:

If most of our students perform poorly we standardise examinations (Lecturer).

The above confirm that norm referencing is resorted to. Norm-referencing is done for the purposes of comparing students' performance. Norm referencing is not ideal for conflict resolution because it is linked to competition.

\section{Management Practices and Conflict Resolution in Teachers' Colleges}

Three management practices feature in teachers' colleges. These are the use of the Student Representative Council, use of wardens and the use of a disciplinary committee.

\section{Use of Student Representative Council (SRC)}

The teachers' college uses the Student Representative Council to get across the views of students to the college authorities. These hold meetings with the college management. The students' complaints are aired to college authorities through the SRC.

Students had this to say:

We voice our complaints through the SRC and get what the college authorities want from us. The college rules are, however, handed over to us we do not have any say in their making (Student teacher). 
Saiden, T. (2017). Towards Conflict Transformation and Management skills' training in Zimbabwean Primary School Teacher Education for effective Teaching, Learning and Peace in Zimbabwean Primary School: A Case Study of Mkoba Teachers' Training College. Advances in Social Sciences Research Journal, 4(16) 1-22.

We are also taught ways of managing our classes and ways of managing schools in some courses (Student teacher).

Though the students pass their complaints through the SRC, college rules are handed down to students. Student teachers are taught a lot of ways of managing their classes and schools.

\section{Use of wardens}

Wardens take care of problems that are faced in hostels. Some of the issues handled by wardens include conflict resolution.

\section{Use of Disciplinary Committees}

Teacher's Colleges have disciplinary committees that handle disciplinary issues. Some of the issues handled by this committee are related to normalising relations. Normalising relations pertain to resolving conflicts.

\section{Use of a Teaching Practice Co-ordinator}

Problems relating to differences between students and schools during Teaching Practice are handled by the Teaching Practice Co-ordinator. The Co-ordinator aims at normalising relations. If there is a big problem, then the student might be transferred.

\section{Discussion on Teachers' Colleges and Conflict Resolution Skills' Development}

The Mkoba Teachers' College curriculum is a carrier in a number of areas that are included in the theme self-esteem and social skills. The only sub-themes of this theme not covered are work skills, ethics and good manners.

The college curriculum also covers much under the theme inculcation of conflict resolution skills. Areas not covered in the curriculum are understanding conflict and peer mediation.

Under the theme, promotion of respect for differences of what is covered mainly pertains to their relationships with disadvantaged or disabled people. Work on interdependence of nations is not included so is work on respect for religious and moral values, equality and a commitment to the common good.

With regard to human rights awareness material on children's rights is covered including child abuse, rights to provision, protection and participation from abuse and participation in decision making, respect, rights and responsibilities, food health care, homes and safety and peaceful world are not included. The curriculum covers gender issues in detail.

The teachers' college curriculum does not address issues to do with bullying. This area as pointed out by teachers is quite important to address because it is rampant in schools.

Regarding problem solving skills development the curriculum handles this area adequately.

The findings in the Health and Life Skills Department present a platform for developing conflict resolution skills, knowledge and positive attitudes in quite a number of areas. There is coverage of gender, human rights issues, life skills such as effective communication, decision making, problem solving, self-awareness, interpersonal relationships, empathy, coping with emotions, coping with stress, negotiation and conflict resolution which are areas to be included in a conflict resolution programme as propounded by the Australian Centre for Citizen Education in schools (2012), Morton (1991) and Murray (2000). 
The Teachers' College curriculum employs all methods that are suitable for conflict resolution programme. The content is delivered to students through lectures, discussions, educational visits, research, participatory methodologies and Case Studies that have been recommended by Fountain (1999) and Abebe, Gbesso and Nyawalo (2006) as effective for developing conflict resolution skills.

The teachers' college uses three forms of assessment. But the assessments are to be undertaken on children the student teacher is exposed to. So the student teacher is exposed to the various forms of assessment some of which are suitable for conflict resolution, for example, seminar presentations and assignments.

Students air their views through the SRC and in Applied Education the student teachers are exposed to a number of management practices. They are also taught issues of school management in Professional Studies which include conflict resolution issues.

Focus group discussions with students confirmed the material in the syllabus was delivered in depth except religion which was covered, as it relates to gender only. While negotiation and arbitration were covered areas like peer mediation, academic controversy were not taught.

The student teachers, however, pointed out that while they did Health and Life skills in Teachers' Colleges, when they got into schools they found the HIV and AIDS action programme in operation but did not practise the skills acquired. This is confirmed by Gatawa (1998) expressed that there was a mismatch between school curriculum development and teacher training. This is probably because Teachers' colleges, according to Shumba, Manokore, Silitshena, Sango, Dhlomo and Mhondoro (2005) were relatively autonomous and each college developed independent curricula. Makoni (2015) found out that two teacher education colleges in urban Mutare did not have any peace education programme. What this implies is that colleges prepare teachers using independently developed syllabuses as confirmed by Chivore (1994). It means therefore, that the syllabus reviewed for this college might be different from other syllabuses for Health and Life Skills in other Teachers' Colleges since syllabuses in colleges are designed independently.

The teachers who had recently graduated from colleges confirmed the mismatch between what they found in schools after exposure to the Health and Life Skills programme. The content of the in-service and pre-service Health and Life Skills programme could include such areas as mediation, academic controversy (Johnson and Johnson, 1995), cooperative learning (Johnson and Johnson, 1995; Coleman and Deutsh, 2001) and inclusion (Sadomba and Hlatswayo, 2011). Multicultural Education includes indigenous knowledge system (Matsika, 2012) and inter-faith education that includes teaching about beliefs and values of other faiths (Pring, 2005; Halstead and McLaughlin, 2005; Brighouse, 2005).

\section{CONCLUSIONS}

The following conclusions can be drawn from the findings:

- The teacher education curriculum covers much of the areas on conflict resolution.

- The teacher education curriculum does not cover areas like mediation, ethics and good manners, interdependence of nations, bullying and some college wide strategies like cooperative learning and academic controversy that are appropriate in conflict resolution.

- The methods used in teaching students equipped them adequately with methods of transmitting conflict resolution skills. 
- Assess in teachers' colleges was largely norm-referenced instead of criterion-referenced to make it appropriate to conflict resolution.

- Schools were not practicing what was learnt at teacher education colleges in the Health and Life Skills programme but were still teaching HIV/AIDS education a situation that causes the graduates of teacher educational colleges not to use what they had acquired.

\section{RECOMMENDATIONS}

The following recommendations were drawn from the conclusions stated above;

- The teacher education curriculum to cover areas left out namely mediation, ethics, good manners, bullying, interdependence of nations, cooperative learning and academic controversy.

- The assessment methods in teacher education colleges to be criterion-referenced.

- The school curriculum to be in sync with the teacher education curriculum.

- Further research to be undertaken with the Department of Teacher Education at the University of Zimbabwe to get their views on the imparting of conflict resolution skills in teacher educational colleges.

\section{References}

Abebe, T. T., Gbesso, A. and Nyawalo, P. A. (2006).University of Peace, Report on the working Committee meeting, on Peace Education in Africa, Addis Ababa Ethiopia: University of Peace.

Amatruda, M. J. (2006). Conflict Resolution and Social Skill Development with Children.Heldref Publications JPPS Winter.

Appleby, C. (1994).Modern Business Administration (6 $6^{\text {th }}$ Ed), London: Financial Times Pitman Publishing.

Bloor, M. \& Wood, F. (2006). Keywords in qualitative research: A vocabulary of research Concepts. London: Sage.

Brighouse, H. (2005). Faith- Based Schools in the United Kingdom: An Unenthusiastic Defence of a slightly Reformed Status Quo. In Gadner, R. Cairns, J. \& Lawton, D. (Eds) Faith schools Consensus or Conflict, London: Routledge Falmer: 83-89.

Chakanyuka, S. (1995).Measurement and Evaluation in Education Module (EA3PD 304) Harare: Zimbabwe Open University.

Centre for Citizenship Education in Schools (2012). Citizenship Education in Europe, Enoydice.

Chivore, B. R. S. (1994).The Effectiveness of the Primary School Teacher in Zimbabwe, Gweru: Mambo Press.

Cohen, R. (1995).Students Resolving Conflict Glenview IL: Good year Books.

Coleman, P. T., \& Deutsch, M. (2001). Introducting cooperation and conflict resolution in schools: a systems approach. In D. J. Christie, R. V. Wagner, \& D. A. Winter, Peace, conflict, Cooperation and Conflict Resolution, http://www.knowgangs.com/school resources/menu-022.htm accessed 04/03/2012

Crawford, D. and Bodine, R. (1996). Conflict Resolution Education: A Guide implementing programs in schools, Youth - serving organisations and community and Juvernile Justice settings, Program Report Office Juvernile Justice and DEliquence Prevention: US Dept of Justice and safe and drug free school program. US Department of Education, https://www.nejrs.gov/txfiles/160935.txtb accessed 22/02/2014.

Danesh, H.B. and Danesh, R. P. (2002) "Has Conflict Resolution Grown Up? Towards a New Model of Decision Making and Conflict Resolution" International Journal of Peace Studies7. (1): 59-76.

Daniels, H., Visser, J. Cole, T. \& de Rey Bekill, N. (1998). Emotional and Behaviour Difficulties in Mainstream Schools, Research Report RR90. London: DFEE.

Denzin, N. K. (1997). Interpretive Ethnography. Ethnographic Practices for the $21^{\text {st }}$ Century, Thousand Oaks, CA: SAGE.

Deutsch, M. (2001).The Resolution of Conflict. U.S.A: Zale University.

Douglas, E. (1999). “Making sense of Anger” Special Autumn issue: p8-11. 
Emmelt, J. D. \& Monsour, F. (1996) Open Classroom meetings: promoting peaceful schools.In Elementary School Guidance and Counselling V3 N1 p3 - 10.

Fisher, S., Abdi, D., Lndin, J., Smith R., Williams,S.\& Williams S,, (2007).Working with conflict skills and strategies for action, (2nd Ed) London: ZED Books Ltd.

Fountain, S. (1999). Peace Education in UNICEF: Working Paper Education Sector Programme Division. New York: UNICEF.

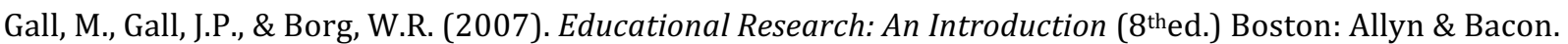

Gatawa, B.S.M. (1990).The Politics of the School Curriculum: An Introduction. Harare: College Press.

Gatawa, B.S.M. (1998).Quality - Quantity Dilemma in Education, Harare: College Press.

Gorter, R. L. (1986).International Collaboration in Curriculum Development, New York: Association for Supervision and Curriculum Development.

Gwarinda, T. C. (1993).The Practice of Teaching, Harare: College Press Publishers.

Halstead, J.M. \& McLaughlin, T. (2005). Are Faith Schools Divisive? In Gadner, R. Cairns, J. \& Lawton, D. (Eds) Faith schools Consensus or Conflict, London: Routledge Falmer: 61-72.

Hantzopolous, M. (2011). Institutionalising Critical Peace Eduction in Public Schools: A case for Comprehensive Implementation. Journal of Peace Education Vol 8 No3 p. 225-242.

Harris, I. M. (2003). Peace Education Evaluation. The Annual Meeting of the American Education Research Association. Education Resource Information Centre (ERIC).

Hatton, K. (2013). Social Pedagogy in the UK. Theory and Practice. Lyme Regis: Russel Publishing Ltd.

Johnson, D.W. \& Johnson, R.T. (1995).Reducing School Violence through Conflict Resolution, Virginia: Association for Supervision and Curriculum Development.

Kasambira, K. P. (1998). Education, Administration and Management, Harare: College Press.

Kaye, P.E and Webb, A. (1996). "A Little Help From My Friends” A Secondary School Peer Support Programme, Pastoral Care in Education June 1996, 21-25.

Lam, J. (1988). The Impact of Conflict Resolution Programs on Schools: A review and Synthesis of Evidence. Amherst, M. A: Research report prepared for the National Association for Mediation in Education (January).

Lederach, J. P. (1997). Preparing for Peace: Conflict Transformation Across Cultures, Syracuse: Syracuse University Press.

Makoni, R. (2015). Peace Education in Zimbabwean Pre-Service Teacher Education. PhD Thesis (Unpublished), University of South Africa.

Makuvaza, N. (2008). Conquest, Colonial Education and Cultural Uprootedness in Africa- the role of Education for Hunhu/ Ubuntu in de- rooting the African in Zimbabwe. In Zimbabwe Journal of Educational Research, 20(3):371388.

Mapolisa, T. and Tshabalala, T. (2012). An investigation into the causes of conflict in Zimbabwean schools: A Case Study of Nkayi South Circuit in Nova Explore Publication Volume 1 No. 1: 1-6.

Marashe, J. Ndamba, G. T. and Chireshe, E. (2009). The Teaching of African Traditional Religion in Primary Schools in Zimbabwe challenges and opportunities.University of Pretoria, http://www.tandfonline.com/loi/usea 20.Accessed on $20 / 06 / 2015$

Maslow, A. H. (1991). Critique of Self-actualization Theory.The Journal of Humanistic Education and Development, 29(3): 103 -108.

Matsika, C. (2012). Traditional African Education: It's Significance to Current Educational Practices with Special Reference to Zimbabwe, Gweru: Mambo Press.

Mavhunga, P. J. (2006). Africanising the School Curriculum: A case of Zimbabwe.Zimbabwe Journal of Educational Research, 18(3):440-456.

McEachern, A. G., Kenny, M., Blake, E. \& Aluede, O. (2005). Bullying in Schools: International variations.McEachern, A.G. Kenny, M., Blake. E. and Aluede, D. (Eds) Peer Victimization in school: An International Perspective Journal of Social Sciences Special issue No. 8: 51-58 Chapter 7.

Merriam, S. B. (2009). Qualitative Research: A Guide Design and Implementation, San Francisco: Jossey Bass. 
Saiden, T. (2017). Towards Conflict Transformation and Management skills' training in Zimbabwean Primary School Teacher Education for effective Teaching, Learning and Peace in Zimbabwean Primary School: A Case Study of Mkoba Teachers' Training College. Advances in Social Sciences Research Journal, 4(16) 1-22.

Miranda, N. and Enchano, C. L. (2005). Human Rights Education in Asian Schools: In Human Rights Education in Asian Schools volume VII Integrating Human Rights Concepts into school Curriculum: The Phillipine Experience. Osaka: Asia Pacific Human Rights Information Centre.

Mkoba Teachers' College (2010). Health and Life Skills Syllabus. Gweru: Mkoba Teachers' Training College.

Murray, E. (2000). The World around us: a Thematic Primary-Level Curriculum for Children's Rights Education, New York: UNICEF.

Nelson, J.-R., Martella, R. M., \& Marchand-Martella, N. (2012). Maximizing student learning: the effects of a comprehensive school-based program for preventing problem behaviors. Journal of Emotional and Behavioural Disorders, 10 (3).

O'Connel, G. (1995). "More than guardian angels, Managing Schools Today, 4(8): 20-22.

Palmer, J. (2001). Conflict resolution: strategies for the elementary classroom. The Social Studies , 65-68.

Pandey, S.(2011). Professionalisation of teacher education in India: A critique of teacher education curriculum reforms and its effectiveness,1-13. Available from http://www.icsei.net/icsei2011/Full\%20Papers/0007.pdf.(Accessed: 07/07/17).

Petrie, P., Buddy, J., Cameron, C., Wigfall, V. \& Simon, A. (2006). Working with children in Care-European Perspectives. Maidenhead: Open University Press.

Posner, G. (1995).Analyzing The Curriculum (2 ${ }^{\text {nd }}$ ed) New York: McGraw-Hill Inc.

Pring, R. (2005). Faith Schools Can they be Justified. In Gadner, R. Cairns, J. \& Lawton, D. (Eds) Faith schools Consensus or Conflict, London: Routledge Falmer: 51-60.

Robbins, S. P. (1993). Organizational Behaviour (6 $6^{\text {th }}$ Ed) New Delhi: Prentice- Hall of India Pvt Ltd.

Robbins, S. P. (2001). Organizational Behaviour (9th Ed) New Delhi: Prentice- Hall of India Pvt Ltd.

Rue, L.N. and Byars, L.L. (2003). Management: Skills and Application (10 $10^{\text {th }}$ Ed) Boston: McGraw Hill Irwin.

Sadomba, F.C. \& Hlatswayo, L. (2012). Conflict Management and Transformation in Education.Module BEDM 308. Harare: Zimbabwe Open University.

Salisbury, J. and Jackson, D. (1996). Challenging Macho Values, London: The Falmer Press.

Sellman, E. M. (2003). The Process and Outcomes of Implementing Peer Mediation Services in Schools: A Cultural Historical Activity Theory Approach. Unpublished, D. Phil Thesis University of Birmingham.

Shumba, O., Manokore V., Silitshena, P., Sango, G., Dhlomo, T. \& Mhondoro, K. (2005). Analysis of opportunities and Gaps in Teacher Education Curriculum on growing up and survival maturation: Zimbabwe Journal of Educational Research Vol no 2.

Silverman, D. (2010. Doing Qualitative Research, A Practical Handbook. London: Sage.

Ssenkumba, M. (2010). ABaseline Survey report on school-based Peace Education and Guidance and Counselling in Secondary Schools in Northern Uganda, 1-60. Available from

http://www.endchildsoldering.org/documents/BaselinSurveyReport.pdf (Accessed 6,6/17).

Stoner, J. A. F., Freeman, R. E. and Gilbert, Jr D. R. (1995). Management.(6 ${ }^{\text {th }}$ Ed) Englewood Cliffs: Prentice-Hall incl.

Team Zimbabwe (2015).Non Ndebele Speaking Teachers in Matebeleland. teamzimbabwe.org/nondebele speaking - teachers - matebeleland.Accessed on 06/05/2015.

ThemPra (2015). Social Pedagogy Community Interest group.www.socialpedagogy.co.uk accessed 12/02/2015.

Tumbo, D. and Moyo, E. (2013). Key Informants Research Report on Conflict Prevention, Management, Resolution and Transformation for in school Zimbabwean Children, Harare: Environmental Action.

University of Florida College of Education (2012). Conflict Resolution and Social problem solving: Curriculum Materials Managing Student Behaviour: Gainesville: Norman Hall.

Unwin, R. and Osei, I. (2000). "Peace education, Peer Mediation and development education, The Development Education Journal, 6(2):4 -7.

Zimbabwe Report of the Presidential Commission of Inquiry into Education and Training, Nziramasanga, C. T. (1999). Harare: Government Printers. 